\title{
小型電算機によるラジゥム線源の線量分布計算
}

\author{
愛知県がんセンター 放射線治燎部（部長 森田皓三） \\ 放射線技術科（科長，植田俊男） \\ 内山幸男・高橋一広・植田俊男 \\ （論文受付，昭和51年 7 月17日）
}

(Code No. 41111, 41250, 43134)

\section{CALCULATION OF DOSE DISTRIBUTIONS OF RADIUM SOURCES BY A MINI COMPUTER}

(Article received: July, 17, 1976)

\section{By YUKIO UCHIYAMA \\ KAZUHIRO TAKAHASHI \\ TOSHIO UEDA}

Technical section, Department of Radiation Therapy:

Aichi Cancer Center. Chikusaku Nagoya Japan.

\section{Summary}

Quimby system or Paterson-Parker system have been applied in clinical use as a reliable guide for the dose evaluation of intracavitary implantation of radium sources. Since the sources in the patient are never exactly as prescribed geometries, it is better that the calculation of dose distribution should be based upon the arrangement of the sources in the individual patient. Several computer methods for these dose estimations have been developed, and for the calculation, the methods of accurate approximations have been reported for these fifteen years. In this report, the program and the method of approximations to compute the dose distribution for actual implantation at the routine work with mini-computer were discussed.

Conversational mode was applicated to obtain the input data, so the input errors could be easily found out and could be quickly corrected by the key board. The formulas of approximation reported by 4 authors were combined and compared each other, to find out the suitable computation. The images magnified on localization films were corrected to actual length of the sources automatically. Simpson's numerical integral was applied in case of the approximation for the absorption of Pt-filter and for water-air-ratio. The calculation was carried out regarding the line source as five-point sources. The doses were measured in a polystyrene cube phantom with insertion of $10 \mathrm{mg}$ radium tube, and the calculated value agreed well with the experimental value.

The dose distribution can be obtained on any desired plane. The area, which was printed out dose distribution, can be easily selected, therefore, the time is saved. 


\section{1. 緒言}

ラジウムを使用する腔内照射の臨床的な線量評洒につ いては, Patterson-Parker の表122)3)等により，腫煬の容 積に応じた適当な線源の配列を行ない，投与線量をあら かじめ決めて照射時間を計算する方法が，臨床的には効 果的な方法として採用されてきている。しかし，患者内 に挿入された線源は計画された通りに正確に配列される 事は殆どあり得ないため，個々の患者に対して挿入され た線源の配列を基にして電算機による計算を行なった方 が理想的である．電算機によるこの種の計算はすでに多 く報告があり，計算法については比較的精度の良い近似 式が発表されて来ている4)へ10).

本論文においてはラジウムによる腔内照射の線量計算 と線量分布の描写が日常業務において容易にできるよう に，小型電算機を使用している実際的な事項，及びプロ グラムするまでに検討した事項について述べようと思う。

\section{2. 電算機及びプログラム}

電算機はPDP-12 (DEC 社製) で，8Kワードのメモ リ一を持つ中共処理装置, 小型磁気テープ装䈯, 入出力 用タイプライターより成る。

プログラム言語は, FOCAL-8K (Formulating On-line Calculating in Algebric Language) を使用した。この 言語は本電算機族に対し開発された会話用式言語で入力 メッセージ対する応答を亘ちに得る事が出来る。即ち BASIC に似ているが，それと同程度にプログラミング が容易であり, 定数の変更, 修正加容易に出来るように なっている，そのため短期間にプログラムが完成でき， 手直しがすぐに出来る。

プログラムは入力時の䛊りを可能な限り少なくするた め, 挿入されている線源の座標, 線量を求めたい位置, 基準とする位置の坐標は, すべて電算機からの質問の形 で Type され，それに刘㦄する值を大力する形式をとっ た。

計算のプログラムは下記の二つに区分した。 即ち

1) シュミレーターによって撮影した正側のX線㝵真 上での線源の位置の座標を直接入力する事により, 桩大 率を求めて体内の線源及び $\mathrm{A}$ 点， $\mathrm{B}$ 点の座標艺計算す る.

2）1)の值をもとに指定した点の線量，基準点の線量 を計算する，必要とする位置の断面における線量分布を， 基準点の線量を $100 \%$ として計算し出力する．線量分布 を必要とせず線量値のみを得たい場合は，入力時に選択
出来るようにしてあ

る.

この二種のプログ

ラムは，磁気テープ

上にファイルされて おり，相互に読み込 むととによってシス テム化している。 ト ータルプログラム, ブロックフローを

Fig. 1 亿示す.

\section{3. 入力の方法}

入力は計算機から 質問の形で文字が印 字されて来るので， それに応じた数值， 記号をタイプライタ ーによって印字す る.まず線源の本数 が質問されるので挿 入されている線源の 数を入力する。次に 入力した線源の数に 対応した夫々の線源 の両端の座標值とそ の線源の容量 $(\mathrm{mg}$ 単位)の質問に対し， 対応した值を入力す る。最後汇計算した い平面の種類と，その位置を入力する．座標軸は体の左 在方向を $\mathrm{X}$ ，前後方向を $Z$ ，上下方向を $\mathrm{Y}$ 之決めている ので，横断面は $X, Z$ 軸を含む平面となり，前後面は $X$, $Y$, 矢状面は $Y, Z$, と夫久記号で入力する。計算面己。

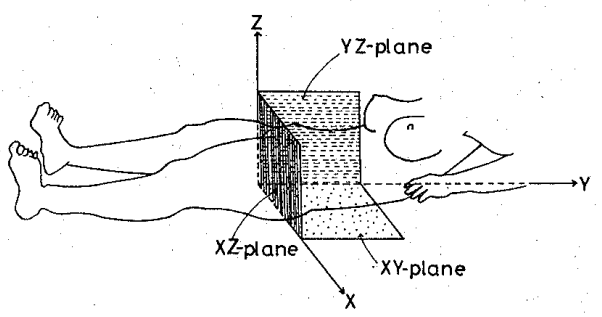

Fig. 2. The available calculation plane relative to the patient position. Each plane can be set in any desired position in our program. 
座標軸の関係を Fig. 2 亿示す。即ち，計算面の種類とそ れに直交する軸の座標を与える事によって任意の面の計 算が出来るようにしてある，最後に指定した計算面にお ける計算範囲を入力する，乙れは必要最少限の範囲の計 算を行なう事によって処理時間を短くするためである。

\section{4. 出力の形態}

計算結果の記録はすべてタイプライ゙ターによって印字
される，計算面の種類とその座標，夫々の線源ごとの座 標とその容壆 (mg), A点, B点の座標之夫々の位置で の線量值などが表にして印字される。乙れらの座標值は X線写真加ら読えだ值を拡大率によって補正した真の値 に修正されている。

線量分布は，線源の周团 $5 \mathrm{~mm}$ 以内は計算を省き，計 算間隔の升目はタイプライターの活字と間隔を合わせて, 縦軸 $3.3 \mathrm{~mm}$, 横軸 $5 \mathrm{~mm}$ 亿して步る. 横軸方向の 計算

***dose distribution for interstitial and intracavitary implantations*** (X-Y plane)
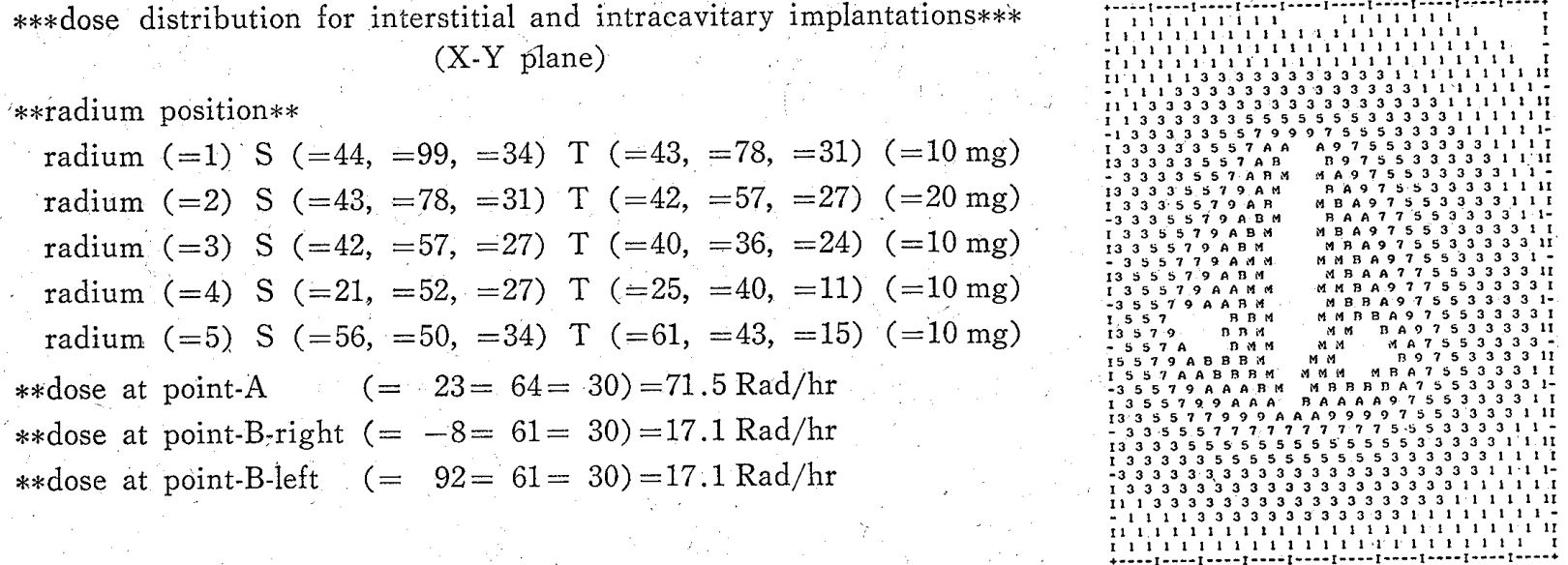

Fig. 3. Computer print-out of dose distribution around the five radium sources. On the plane of $\mathrm{X}-\mathrm{Y}$.

***dose distribution for interstitial and intracavitary implantations*** (Y-Z plane)

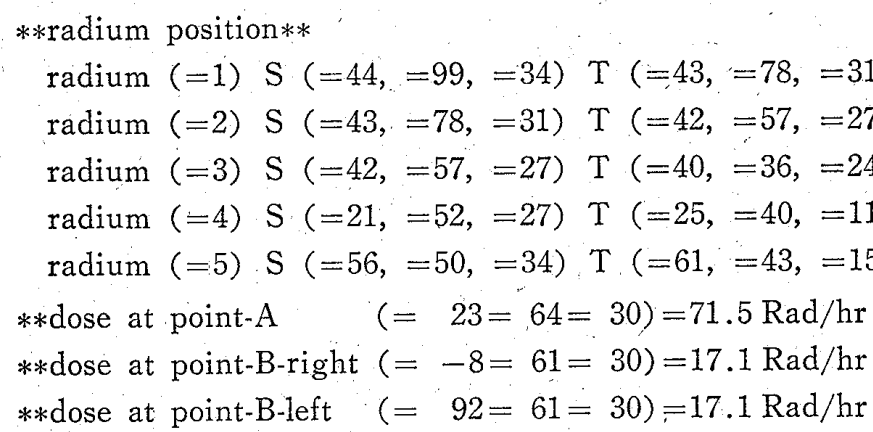

Fig. 4. On the plane of $\mathrm{Y}-\mathrm{Z}$.

***dose distribution for interstitial and intracavitary implantations*** (X-Z plane)
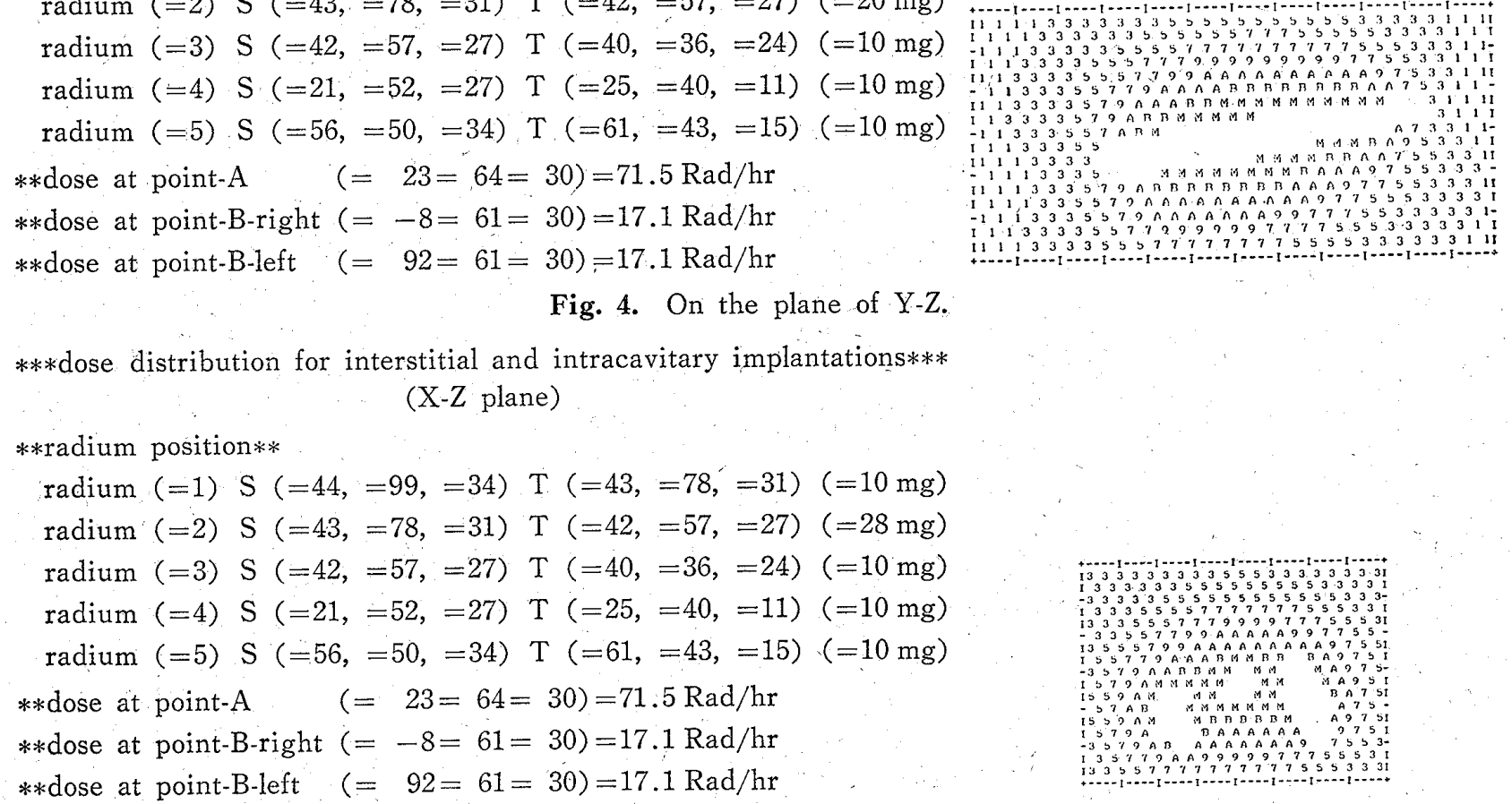

Fig. 4. On the plane of X-Z.

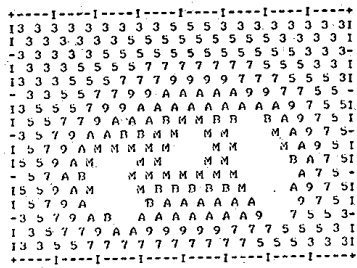


は印字一つに間隔一つ置くことにして，印字の並びが基 盤状でなく千舄状に配列し，印字が均等になるようにし た。線量域は $\mathrm{A}$ 点の線量を $100 \%$ として， $\mathrm{M} \geqq 200 \%$ ， $150 \leqq \mathrm{~B}<200 \%, 100 \leqq \mathrm{~A}<150 \%, 80 \leqq 9<100 \%, 60 \leqq$ $7<80 \%, 40 \leqq 5 \leqslant 60 \%, 20 \leqq 3<40 \%, 10 \leqq 1<20 \%$, 空 白 $<9 \%$ として表示するようにした。

ラジウム管をタンデム状に $10 ， 20 ， 10 \mathrm{mg}$ と 3 本使用 し，オボイド状に $10 \mathrm{mg} 2$ 本を配列した実際の治療患者 の線量分布図を，Fig. 3, Fig. 4, Fig. 5亿示す.とれら の図は夫々前後面，矢状面，横断面の計算結果を示すも ので、計算範围は印字したい範囲に応じて入力時に指定 してあるので図の大きさが夫々異なっている．分布の楛 の目盛は横軸 “I……I”間が $1 \mathrm{~cm}$ 亿なっている.

\section{5. 計算の方法}

標準ラジウム線源は容器の端から有効部の端までの間 隔が両端で比較すると異なっているが，本售算において は全長と有效長から夫久両端の長さを同じとし, 容器の 端の形態はその径と同じ半球状をなすすのとして処理し た. 全長, 有效長及び容器の壁厚及び壁厚の变化の判定 は，ラジウムの量に応じて table look up 法によって処 理するようにしてある，以上の処理以外に計算の基にな る線源加らの距離, $r$ 線の通過する容器の厚みなどは三 次元の幾何学的計算に過ぎないので省略する.

照射線量率は，白金の吸収之WAR（Water Air Ratio）の値を近似式によって計算し, Simpsonの公式で 数值積分を行なう方法をとった. 即ち, Fig. 6 に示すよ う

$h:$ 線源加ら計算点までの垂直距離

$\bar{d}$ ：線源中心乙計算点までの長さから通過する容器の 壁厚を除いた長さ

$l:$ 線源の有效長,

$M$ : 線源の放射能

とすると

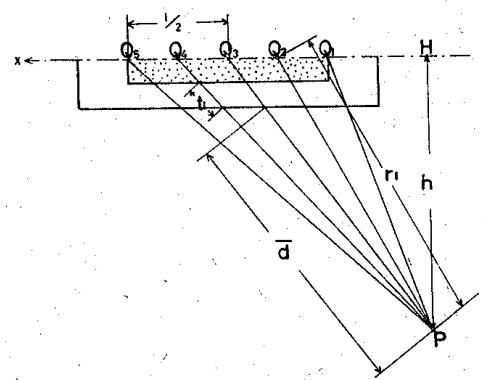

Fig. 6. Geometry of dose calculation for a linear radium source.

$$
\begin{aligned}
& I=\frac{M}{l} \cdot \operatorname{WAR}(\bar{d}) \cdot \frac{l}{3 n} \cdot\left\{b_{0}+b_{n}+4\left(b_{1}+b_{3}+\cdots+b_{n-1}\right)\right. \\
& \left.\quad+2\left(b_{2}+b_{4}+\cdots b_{n-2}\right)\right\} \\
& \text { 但し } \quad b_{i}=\frac{\Phi t_{i}}{r_{i}} \quad i=0,1,2, \cdots, n,(n=\text { 偶数 })
\end{aligned}
$$

となる.nは分割数で本計算では $\mathrm{n}=4$, 即ち 5 つの点 線源として近似積分を行なった．白金の吸収とWARの 近似式ば尾内 ${ }^{4} の$ 発表のものを採用した。

\section{6. 近似方法の検討}

小型電算機のように小容量のものを使って計算を行な うと計算時間が長くなるので，出来る限り計算時間を少 くするためには近似式す簡単なすのが良い，そこで前述 の計算方法で述べた近似式，分割数を決めた理由を述べ る。まづ白金の吸収之WARの計算方法で 現在まで 報 告されている近似式の内，比較的簡単なすのを選び，そ れらを互に組合せて計算し比較してみた。乙の内白金の 吸収 $(\Phi) 、 の$ 計算式は， $\mathrm{t}$ を $\mathrm{cm}$ 単位で表わしたとき

$\Phi_{H}=1.82 \exp (-6.2 t)+7.6 \exp (-0.99 t) \cdots \cdots \cdots(2)$

$\emptyset_{0}=8.798-12.73 t+10.36 t^{2}-3.761 t^{3}$

の 2 種を使用した。（2)式はHope（3)式は尾内によ るものである。組織による減弱 (WAR) の計算式は， $\mathrm{d}$ を計算点から線源容器表面までの巨高とすると

$$
\begin{aligned}
& \mathrm{WAR}_{B}=1-0.0074 d^{3 / 2} \\
& \mathrm{WAR}_{A}=1-0.02 d \\
& \mathrm{WAR}_{0}=1.000-0.00161 d-0.0004435 d^{2} \cdots \cdots \cdots(6)
\end{aligned}
$$
を使用した。（4)式は Batho（5)式は Adams，(6)式 は尾内によるものである。

上記白金の吸収の近似式 (2)，（3）の夫々について， WAR の近似式 (4)，（5），（6)を組合せ線源の中央加 ら直角方向に（Fig.7のY方向）距離をとり，5cm まで を計算した． Table 1 そこの結果を示す．表は $10 \mathrm{mg} の$ ラジウム管，実效長 $1.5 \mathrm{~cm}$, 全長 $2.17 \mathrm{~cm}$ ののにつ いて $\mathrm{n}=10$ として計算した值で，第 1 欄は線源中央から 直角方向の距離，第 2 欄にQuimby ${ }^{12}$ そよって測定され た值，第 3 骤〜第 8 欄は前の略字が白金の财収を計算し た近似式の記号, 後の略字が同様にWARの近似式の記 号を示す. 即ち $\mathrm{O}, \mathrm{ON}$ : 尾内, $\mathrm{AD}$ : Adams, H: Hope, BA：Bathoを示す．何れの組合せで計算しても全体に わたって殆んど大きい差はなくほぼよく近似しているて とがわかる.Quimby の值と比較して尾内による近似式 が比較的よく一致し線源からの距離 $0.75 \mathrm{~cm}$ 以上では, $1 \%$ 以下の㟪差範团であった。

（1）式の Simpson の近似積分公式は n の值 が大きい 程近似は良くなるが，計算する場合にはnの値が少い程 
Table 1. Results of dose rate culculation for a $10 \mathrm{mg}$ radium sources obtained with the combination of 4 authors' equation for the absorption of $\mathrm{Pt}$-WAR.

\begin{tabular}{|c|c|c|c|c|c|c|c|}
\hline \multirow{2}{*}{$\begin{array}{l}\text { Distance } \\
\text { from the } \\
\text { source } \\
(\mathrm{cm})\end{array}$} & \multirow{2}{*}{$\begin{array}{l}\text { Quimby's } \\
\text { data }\end{array}$} & \multicolumn{6}{|c|}{ Combination } \\
\hline & & $\mathrm{O}-\mathrm{ON}$ & $\mathrm{O}-\mathrm{AD}$ & $\mathrm{O}-\mathrm{BA}$ & $\mathrm{H}-\mathrm{ON}$ & $\mathrm{H}-\mathrm{AD}$ & $\mathrm{H}-\mathrm{BA}$ \\
\hline 0.50 & 182.7 & 185.5 & 180.4 & 181.8 & 187.1 & 185.3 & 186.7 \\
\hline 0.75 & 98.5 & 100.1 & 98.4 & 99.4 & 102.6 & 101.2 & 102.2 \\
\hline 1.00 & 61.3 & 61.8 & 60.7 & 61.5 & 63.7 & 62.5 & 63.3 \\
\hline 1.50 & 29.8 & 29.8 & 29.0 & 29.5 & 30.8 & 29.9 & 30.4 \\
\hline 2.00 & 17.3 & 17.3 & 16.7 & 17.0 & 17.9 & 17.2 & 17.6 \\
\hline 2.50 & 11.2 & 11.3 & 10.8 & 11.0 & 11.6 & 11.1 & 11.3 \\
\hline 3.00 & 7.8 & 7.9 & 7.8 & 7.6 & 8.1 & 7.7 & 7.9 \\
\hline 3.50 & 5.8 & 5.8 & 5.5 & 5.6 & 6.0 & 5.6 & 5.8 \\
\hline 4.00 & 4.5 & 4.5 & 4.2 & 4.2 & 4.6 & 4.3 & 4.4 \\
\hline 4.50 & 3.5 & 3.5 & 3.3 & 3.3 & 3.6 & 3.4 & 3.4 \\
\hline 5.00 & 2.9 & 2.9 & 2.6 & 2.7 & 2.9 & 2.7 & 2.7 \\
\hline
\end{tabular}

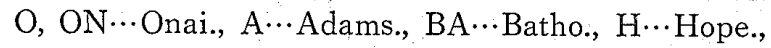
O-BA means combination of Onai's equation of the absorption of $\mathrm{Pt}$ and Batho equation of WAR.

Table 2. Changes of calculation results $(\mathrm{Rad} / \mathrm{h})$ depending on the $n$ value of Simpson's numerical integral for a $10 \mathrm{mg}$ radium source. Filtration $=1.0 \mathrm{~mm}$ Pt. Active length $=1.5 \mathrm{~cm}$.

\begin{tabular}{c|r|r|r|r|r|r}
\hline $\begin{array}{r}\text { Distance } \\
\text { from the } \\
\text { source } \\
\text { (cm) }\end{array}$ & $\begin{array}{c}\text { Quimby's } \\
\text { data }\end{array}$ & \multicolumn{5}{|c|}{$\begin{array}{c}\text { Number of division of a } \\
\text { active length }\end{array}$} \\
\hline 0.50 & 182.7 & 248.0 & \multicolumn{1}{|c|}{4} & 6 & 8 & 10 \\
0.75 & 98.5 & 127.1 & 99.8 & 100.1 & 100.1 & 100.1 \\
1.00 & 61.3 & 78.6 & 61.8 & 61.8 & 61.8 & 61.8 \\
1.50 & 29.8 & 38.5 & 29.8 & 29.8 & 29.8 & 29.8 \\
2.00 & 17.3 & 22.6 & 17.3 & 17.3 & 17.3 & 17.3 \\
2.50 & 11.2 & 14.8 & 11.3 & 11.3 & 11.3 & 11.3 \\
3.00 & 7.8 & 10.4 & 7.9 & 7.9 & 7.9 & 7.9 \\
3.50 & 5.8 & 7.7 & 5.8 & 5.8 & 5.8 & 5.8 \\
4.00 & 4.5 & 5.9 & 4.5 & 4.5 & 4.5 & 4.5 \\
4.50 & 3.5 & 4.7 & 3.5 & 3.5 & 3.5 & 3.5 \\
5.00 & 2.9 & 3.8 & 2.9 & 2.9 & 2.9 & 2.9 \\
\hline
\end{tabular}

計算時間は少なくてすむ.そこでnの值を 2 〜 10 まで変 化させた時, 計算結果にどの程度差があるかを確かめて みた. TABLE 2 はとの結果を示すすので,表の第 3 欄か ら第 7 闌までに夫々分割数 $\mathrm{n}$ の值をとってある。近似計 算は (3)，（6)式を組合せて計算したものである。表よ り $\mathrm{n}=2$, 即ち 3 点の阡算では Quimby の值と比較し
て，かなりの差があるが 4 分割 5 点以上であれば計算值 はよく一致し，線源加 $1 \mathrm{~cm}$ 以上離れれば $\mathrm{n} か ゙$ 多くな っても計算値は殆じ差が無くなることが解る. 従って最 小のnの值は 4 即ち 5 点の計算で大きな䛊差はないとと になる。

\section{7. 実測值との比較}

線量の垁測には mble 社製 Reader：PNH 751，Dosimeter: PNP 281, TLD 線量測定器を使用した。素子は $\mathrm{CaF}_{2}$ (mble 社製) で長さ $3.5 \mathrm{~cm}$, 径 $0.595 \mathrm{~cm}$ のロッ ド状のあのである．素子はコバルトー $60, \gamma$ 線によって あらかじめ数回の曝射を行ないアニリングを繰り返して Pre-dose が残らずしかも再現性の良いあのを選び，コ バルトー60，r線を基準とした読みによる校正を行なっ た.ファントムは一辺 $15 \mathrm{~cm}$ の立方体でポリスチレン 製のものを使用した：ファントムは二分出来るようにな っており，中央に $10 \mathrm{mg}$ ラジゥム管の入る涶及びその 位置の中央加らの垂直距離で $2 \mathrm{~cm}$ 及び $5 \mathrm{~cm}$ の位置に TLD 素子が挿入出来るようにしたものである。曝射時 間は 5 時間とした。

測定結果は $2 \mathrm{~cm}$ の点で $17.4 \mathrm{rad} / \mathrm{h}, 5 \mathrm{~cm}$ の点で 2.87 $\mathrm{rad} / \mathrm{h}$ であった．とれらの值は前述の表の結果と殆ど一 致している。

\section{8. 考案}

\section{1 実測值と計算値について}

密封小線源治療では照射部位と線源との距離が近いの で実測する際には線量計の設定の正確さが測定結果に最 も大きく影響するととが考えられる。私共が $2 \mathrm{~cm}$ と 5 $\mathrm{cm}$ の点でのみ実測を試みたのは，今迄発表されてきた 計算方法について実測との差がよ゙の計算式を用いても 1 〜2\%以内で一致することが報告されているからであ る. 更に TLD 素子が電離箱型の線量計に比しその容積 が小さいとは言え線源により近い点に於てはその大きさ についてあ無視出来ないてとを考え，いたづらに測定を 繰り返すより 2 点程度の测定で確認を行なった後今迄発 表された計算式を利用した方が能率的であり正確と考え たためである.外部照射に打ける梁部率曲線については すでに棒準的なあのが出版されて居り，てれらによって 測定結果の比較検討が可能であるがラジウム線源でての 種の公式な出版は少いようであり比較すべき値の基準を ごれにするか判断に苦しんだからである。

白金の吸収及びWAR の計算の近似式については，6 で述べた組合せによって線源と直角方向及び線源中央か 


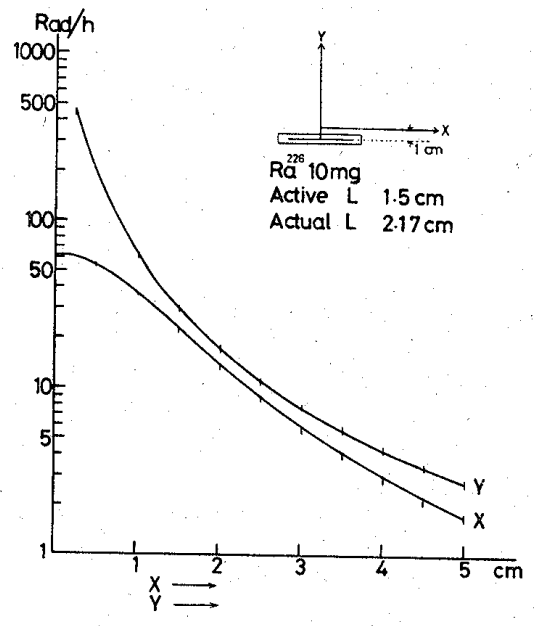

Fig. 7. Deviation (small bar) of the results of dose calculation along the $\mathrm{X} \& \mathrm{Y}$ axis in figure obtained with the conbination of 4 author's equation for the absorption of $\mathrm{Pt}$ and for the WAR. Solid line...... Quimby's data.

ら $1 \mathrm{~cm}$ 離れた平行方向に夫々計算した結果いづれむ大 きい差が無いととを確認した.Fig. 7 にその模様を示 す. 図は横軸に線源からの距離をとり縦軸に吸収線量率 をとったもので Quimby の測定結果を実線で, その値に 対する各組合せの計算値の偏差值の範囲を線状で示した あのである。

\section{2 プログラムの問題点と意義}

本計算において入力機構を電算機との対話型式とした のは大力時の操作に誤りが少く，かつ愦った值を入力し た場合でも直ちに訂正が出来るからである．操作は一定 の単純な順序に従い電算機からの問に答えるようタイプ ライターを操作するのみですみ，電算機に対する知識が 無い人でも容易に扱う事が出来るのは利点と言えよう。 ただし記憶容量が少いためと会話型式プログラムの解読 に対する電算機内での処理が必要となるため, 計算時間 が長くなる事がやや難点といえよう。一本のラジウム管 亿対し一点の計算時間が約 1 秒必要とし, 線源を 5 本使 って $10 \times 10 \mathrm{~cm}$ の範畴の分布を描写すると約50分必要 である. 従って出力型式は, 定められた点の線源のみを 出力する型と線量分布む共に描写する形態のいづれです 選択出来るように二つに分けてあり，入力時に選択する ようにしてある. 計算結果に比較的噿差が少く最小の分 割数として $\mathrm{n}=4$ を採用し，線量分布の描写に計算範 囲を必要最小限に選択するようにして処理時間を短くす るようにして能率化を計ったのは本プログラムの利点と いえよう。
線量計算には比較的記憶容量の大きい大型の電算機を 使った報告が多い. 大型の電算機はどちらかといえば, バッチ妈理のような一つのプログラムで同じ形式のデー ターカードを高速で入力し処理する方法に対して適して 居る.ラシウムの線量計算のように比較的入力データー の少いものに対しては, On-Line-Real-Time で処理し入 カデーターの譟りを確認しながら行なう小型電算機の方 が理想的であろう。

\section{9. 総 括}

密封小線源照射の体内線量分布及び必要とする点の線 量率の計算を症例ごとに日常業務として能率的に行なえ るように小型電算機に対するプログラミングを行なっ た、線量計算の近似式は，尾内らの式を採用し Active length $1.5 \mathrm{~cm}$ のラジウム管の場合 $(10 \mathrm{mg}, 20 \mathrm{mg}) 4$ 分割 5 点であっても実測及び Quimby らの值とよく一致 した．正側のX線写真から読み込んだ座標を線源の実寸 から正確に真の座標に変換し，三次元座標で任意の平面 の線量分布が得られるようにした。

本論文の要旨は，昭和50年10月 2 日富山に拈ける日本 放射線技術学会中部地方会及び昭和50年11月23日名古屋 における日本医学放射線学会中部地方会に於て発表した.

\section{文 献}

1) Johns.: The Physics of Radiology, Charles C Tho mas., pubiisher., Springfield. Illinois. USA., 1964.

2) Paterson R., Parker H. M. and Spiers F. W.: A system of dosage for cylin-drical distributions of radium., Brit. J. Radiol., 7, 487, 1936.

3) Paterson R. and Parker H. M.: A dosage system for interstitial radium therapy., Brit. J. Radiol., 11, 253-313, 1938.

4）尾内能夫，入船寅二，都内禎三：ラジウム治療に扔 ける線量分布の計算. 日医放誌. 28. 1629-1635. 1969.

5）尾内能夫，入船寅二，都丸禎三：放射線治療におけ る線量計算への電子計算機の利用について, Radioisotope. $17,453-466,1968$.

6) Shaiek R. J. and Stovall M.: The M. D. Ander son method for the computation of isodose curves around interstitial and intracavitary radiation sources., Am. J. Roentgenal., 102, 662-672, 1968.

7) Young J. and Batho H. F.: Dose table for linear radium sources calculated by an electronic com- 
puter., Brit. J. Radiol., 37, 38-44, 1964.

8) Batho H. F, and Young M. E. J.: Tissue absorption correction for linear radium sources., Brit. J. Radiol., 37, 682-689, 1964.

9. Adams G. D. and Meurk M. L.: The use of calculate isodose information sorrounding distributed. gynaecological radium sources., Phy. Med. Biol., 9, 533-540, 1964.

10) Hope C. S., Laurie J., Orr J. S,: and Walters J. H.: Phys, Med, Biol., 9, 345-357, (1964)

11) Wootton P., Shalek R. J. and Fletcher G. H.: Investigation of the effective absorption of radium and cobalt so gamma radiation in. Water and its clinical significance., Am. J. Roentgenol., 71, 683-
$690,1954$.

12) Otto Glasser., Russell H. Morgan., Edith H. Quimby., et al.: Physical Foundations of Radiology., 1961 by Paul B. Hoeber, Inc., Printed in the United States of America.

13) Quimby E. H.: Dosage table for linear radiums sources., Radiology., 43, 572, 1944.

14) Meredith W. J., Greene D. and Kawashima K.: The attenuation and scattering in a phantom of gamma rays from rationuclides used in mould and interstitial gamma ray therapy., Brit. J. Radol., 39, 280-286 1966.

15) Mayneord W. V., and Roberts J. E.: Brit. J. Radiol., 10, 365, 1937. 